\title{
MARKET NICHE AS A METHOD OF BRAND PROMOTION
}

\author{
Olena Boienko', Oleksii Susidenko²
}

\begin{abstract}
The purpose of the paper is to prove that market niche is one of the methods of brand promotion. Methodology. To do research, we need to use theoretical and empirical methods. Analysing the Interbrand Ranking, we used methods of comparison, concretization, and generalization. Brand value trend was studied using the method of graphics modelling. To study the definition of "market niche," there were used methods of comparison, generalization, and synthesis thanks to that we defined the special features of this concept. Results. The brand is a relatively new concept, which was developed in the second part of the 20th century. According to the results of this ranking in 2016, the most successful brands were Apple, Google, and Coca-Cola. These brands have the long history and their own experience of doing business in the scale of the global market. One reason for their success is the right selection of a market niche. It was defined that the market niche might be characterized by the next features: highly individual needs and requirements for satisfying which it is necessary to have a range of complement goods and services; stable market potential; weak competitors. There were interviewed several chief-executives of big Ukrainian companies and analysed the most successful and profitable market niches for today. These are: Internet resources: big data; online courses; delivery service; wearable gadget; 3D-printing; robots; fuel cells and batteries; commercial property in regions; smart materials; auto components; health care; recycling; alternative energetics; space; escort of elderly people; franchising business; agriculture; geological prospecting and green projects. Practical implementations. We defined that the brand needs to make six main steps for entering the new market. Firstly, it is necessary to define own niche. Next step is to analyse how external factors influence the brand, which operates in the chosen niche. After this business should analyse opportunities of the brand in this niche, later it is necessary to carry out a SWOT analysis of brand operating in this niche and make the prognosis of the brand operation in this niche and finally prepare the rating of chosen market niches. Value/originality. The results of made investigation might be used by entrepreneurs who are going to set up business because according to the suggested analysis we can see the most profitable niches for coming 10 years.
\end{abstract}

Key words: market niche, non-material asset, brand, marketing tools, competitiveness, range of goods.

JEL Classification: M31, M37, O34

\section{Introduction}

The modern market economy is characterized by the growing role of non-material assets in a business balance. In addition, a strategic success of the business is influenced by interrelation with customers, brand management, and marketing knowledge. A wide range of goods and services in modern markets causes the necessity of solving the problem of competitiveness.

Market conjuncture is characterized by markets fragmentation, high level of competitiveness, and constantly growing requirements of customers to goods quality today. In these conditions, business ought to change, offer new, high-quality goods and services by more beneficial price than competitors do.

Today practice shows that because of the high level of market fragmentation general marketing tools become less effective and cause growing competitiveness. It is necessary to suggest new ideas, which may make the higher profit compared with traditional marketing tools and approaches.

Analysis of modern marketing approaches shows that one of the ways to be ahead of competitors is to find new market niches. In this case, the market niche must be not only a new segment where the business operates, but it also ought to be the potential for growth, the suggestion of new ideas and knowledge that can stimulate demand due to which business enters the new markets, goes ahead of competitors and makes a higher profit. Searching new market niches is important not only for the big business in general but for a brand too, which is the part of non-material assets of this business.

\footnotetext{
Corresponding author:

${ }^{1}$ Vasyl Stus Donetsk National University, Ukraine.

E-mail: o.boienko@donnu.edu.ua

${ }^{2}$ Uzhhorod University of Trade and Economics of Kyiv National University of Trade and Economics, Ukraine.

E-mail: susidenko_av@ukr.net
} 


\section{Investigation methodology and literature review}

In the last publications, we made the conclusion that the brand is a relatively new phenomenon. The brand concept was developed in the second part of the twentieth century. The huge interest for our investigation has publications of $\mathrm{D}$. Aaker, who is a marketing specialist with a focus on the brand strategy. The most interesting for us are these works: "Building Strong Brands" (1996), "Managing Brand Equity" (1991), "Aaker on Branding: 20 Principles That Drive Success" (2014), "Brand Relevance: Making Competitors Irrelevant” (2011). In addition, we analysed the works of J. Liesio, P. Mild, A. Salo (2006) and A. Hines (2008). Exceptional interest works of A. Laut (2011) and B. Tokarev (2012) have because they are devoted to brand success in the frame of searching market niche.

It was made the deep analysis of works mentioned above, although they do not give answers to some questions. They do not give practical bits of advice on how the brand enters the new market through a particular niche. This issue causes the aim of our paper.

In our investigation, we are trying to prove that the market niche is one of the methods of brand promotion. Thus, to do research we need to use theoretical and empirical methods. Analysing the Interbrand Ranking, we used methods of comparison, concretization, and generalization. Brand value trend was studied using the method of graphics modelling. To study the definition of "market niche," there were used methods of comparison, generalization, and synthesis thanks to that we defined the special features of this concept. The most profitable market niches were defined by the method of a survey of chief executives of successful Ukrainian enterprises what allowed us to predict the most profitable niches for coming 10 years. By the method of generalization, we defined factors which explain how the technology brand influences customers' behaviour.

\section{World-known and the most successful brands}

The history of the development of the modern global economy shows the examples of successful conquests of a market by brands, which are known now as famous global ones.

According to the Interbrand Ranking 2016, the first position the Apple brand occupies, Google is the second, and Coca-Cola is the third one (Table 1).

These are the most powerful, famous brands, which have a long history of development and success, and their strategies for entering the new market niches.

For our investigation, it is interesting to review the trend of these brands value (Figure 1).

Given figure allows making such conclusions. Brands value shows growth from 2010 to 2016 . The sharpest positive dynamics characterises Apple's value. This indicator is continuously growing and in 2016 it riches almost 180 billion USD. As to Google and Coca-Cola,

Table 1

The most successful brands in 2016

\begin{tabular}{|l|l|c|c|}
\hline Brand name & \multicolumn{1}{|c|}{ Description } & $\begin{array}{c}\text { Brand value, } \\
\text { million USD }\end{array}$ & Growth rate, \% \\
\hline Apple & Technology brand that uses innovation in producing its gadgets and software platforms & 178119 & 5 \\
\hline Google & Technology brand organising the world's information and making it globally accessible & 133252 & 11 \\
\hline Coca-Cola & Beverage brand which has more than other 500 brands & 73102 & -7 \\
\hline
\end{tabular}

Source: developed by the author based on the Best Global Brands 2016

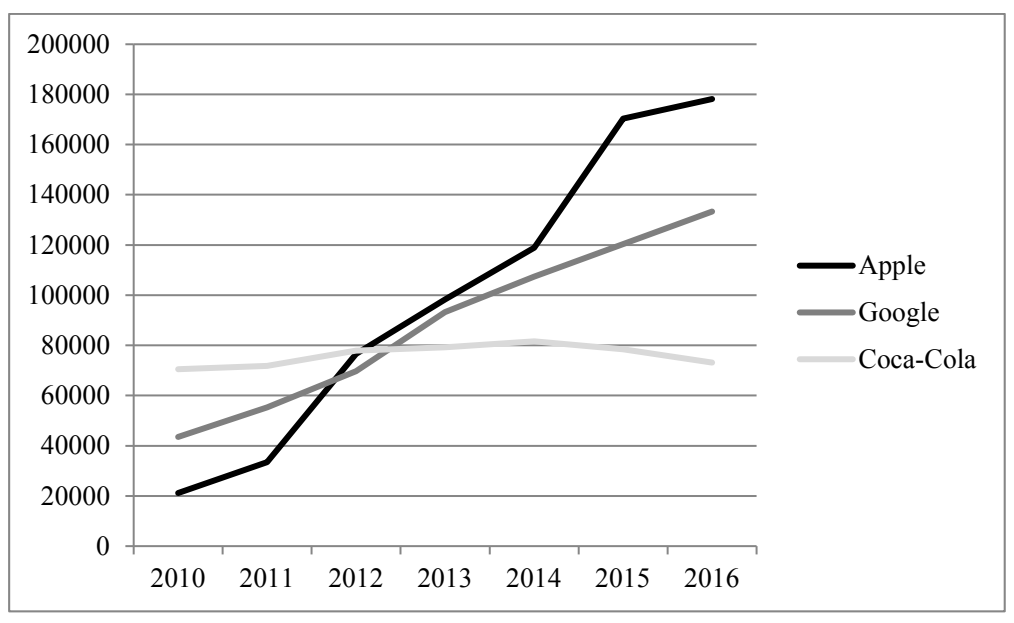

Figure 1. Brand value trend in 2010-2016, million USD

Source: developed by the author based on Table 1 
these brands represent positive dynamics too, but it is not so sharp, it is smoother, and in 2016, Google's value is about 130 billion USD and Coca-Cola's is more than 70 billion USD.

The experience of the given examples is significant. Such success may be possible only if these brands use professional marketing tools, take into consideration customers' demand and study new opportunities and market niches. It is necessary to note that there is no ideal marketing mix for all brands and companies. Although, defining the own marketing niche is an essential step for entering the global market.

\section{Market niche: approaches to understanding}

The definition of "market niche" which is used in the modern economic literature varies significantly. In general, it means the position of the brand in a particular market. Modern marketing does not give single-valued definition. For instance, M. Vaigel (Vaigel, 2004) defines the following variants of using this concept:

identification of concepts of market niche and target market segment;

definition of a small market part, which corresponds to the competitive advantages of the brand;

identification of an unusual situation in the market when the brand satisfies a new requirement that had not been satisfied yet.

When analysing scientific approaches to understanding the concept of a marketing niche, it is important to pay attention to Philip Kotler's vision (Kotler, 2014). In his opinion, the market niche is the sphere of customers' needs thanks to satisfying which the company makes a profit.

Very often modern literature argues that the market niche is a target market, market segment, and marketing opportunity. In this investigation, it is used the definition of M. Vaigel (Vaigel, 2004), who argues that "market niche is free from intensive competition small part of the market which consists of consumers with similar needs which cannot be satisfied fully by existing market products and satisfaction of what can be possible with higher rate of return".

According to our analysis, several features characterise the market niche:

highly individual needs and requirements, for satisfying which it is necessary to have a range of complement goods and services;

stable market potential;

weak competitors.

The market niche is a result of the activity of players in the particular market. So, an appearance of the market niche can be caused by developing different situations in the market. Here we are giving some examples.

Target marketing. It is the orientation on the small part of the market, which is not interesting for large companies (they do not want to satisfy needs of customers in this market), and there is a weak press of competitors on this market.

The unique situation in the market. It is the particular case of special conditions and circumstances of activity (for example, the activity of public bodies that causes the appearance of unique needs of customers that can't be satisfied thanks to existing goods and services.

Clustered marketing. It is the set of loyal customers (focus group) who are interested in receiving a wide range of products and services in a particular place (as an example, one producer, dealer, etc.).

Horizontal marketing. It is widening the range of goods and services oriented on one target segment.

Vertical marketing. It is searching ways of a particular product selling together with complementary products for different groups of customers (on several market segments in one time).

Before exploring the market niche, it is necessary to find a place in the market for your knowledge, skills, and competencies. Many brands have success not thanks to new, innovative products but new ways of entering the market. Today in modern marketing, it is important to use new technologies not only in producing goods but also in ways of cooperating with customers. That is why one of the ways of defining a market niche is innovation in the sphere of selling products and services.

Very often brands that have a small part of the market can be more profitable than the market on an average. The secret of the brand's success, which operates in the market niche, is better concentration on the satisfaction of customers' needs than competitors'. As a result, the company can set a premium price by providing higher compared with competitors' value.

According to the definition of market niche given by M. Vaigel (Vaigel, 2004) and analysed in this paper, we defined the next steps of entering the new market by the brand:

1. Defining criteria for choosing a niche.

2. Analysing the influence of the external environment on the brand operating in the particular niche.

3. Examining opportunities for the brand in the niche.

4. A SWOT analysis of brand operating in the niche.

5. Forecasting of the brand operation in the niche.

6. Preparing the rating of chosen marketing niches.

Time is running, and the needs and requirements of customers are being changed. In these conditions, marketing strategies of brands are being changed too. We made an interview with several chief executives of big Ukrainian companies and prepared the list of modern market niches, which will be profitable next ten years according to the results of the interview (Table 2).

According to the given list, technology market niches are the most popular today. They are the most profitable and perspective for investors. 
Table 2

The most profitable market niches today

\begin{tabular}{|c|l|l|}
\hline № & \multicolumn{1}{|c|}{ Market niche } & \multicolumn{1}{c|}{ Description } \\
\hline 1 & Mobile payments & Technologies and applications for using a smartphone for payments \\
\hline 2 & Internet resources & Technologies that exclude the human participation in repeating operations \\
\hline 3 & Big data & Searching hide interrelations in information space \\
\hline 4 & Online courses & Education online \\
\hline 5 & Delivery service & Food sale online \\
\hline 6 & Wearable gadget & Smart watches, glasses, bracelets, etc. \\
\hline 7 & 3D-printing & Stereo lithography, layer-by-layer fusing, selective laser sintering, 3D printing \\
\hline 8 & Robots & Personal drone, industrial robots, appliances \\
\hline 9 & Fuel cells and batteries & New, more powerful sources of power \\
\hline 10 & Commercial property in regions & Shopping centres, offices, stock in cities with population less than one million \\
\hline 11 & Smart materials & Fabrics, materials with unique features \\
\hline 12 & Auto components & Producing parts of cars \\
\hline 13 & Health care & Private clinics, treatment on the base of the human genome \\
\hline 14 & Recycling & Recycling management \\
\hline 15 & Alternative energetics & Refusal from network electronic energy in favour of small generation \\
\hline 16 & Space & Photos of space, satellites creation \\
\hline 17 & Escort of elderly people & Internet-projects, exoskeletons \\
\hline 18 & Franchising business & Restaurants "Mafia", Good Beer, Everest Mining Company, Indigo Mental Club, Small Fruit, etc. \\
\hline 19 & Agriculture & Feed producing, dairy cattle breeding \\
\hline 20 & Geological prospecting, green projects & Green-projects in the sphere of hydrocarbons and precious metals extracting \\
\hline
\end{tabular}

Source: developed by the author based on the results of survey

\section{Technology brands as examples of success}

According to the Interbrand Ranking 2016 (Best Global Brands, 2016), 13 technology brands show more than $30 \%$ of total value, making technology sector the leader. Modern technology brands have gone beyond launching a successful product or service - they have delivered on the true measure of innovation: the ability to change the perception of customers. Capacity to influence behaviour relies not only on an innovative proposition but also on assessing the value or benefit of that switch to the market.

Here we give the list of factors that explain how technology brands influence customers' behaviour.

Broad addressable markets. It is expected that more than $70 \%$ of the world's population will have mobile phones by the end of 2018. Thus, if you are a gadget producer, microchip maker or internet provider, the market size is enormous. In addition, there are many technology brands that get benefit from a low barrier to entry, especially in comparison with luxury and automotive spheres.

The accessibility of technology brands on the consumer side stimulates the growth on the business side, as the number of connected users contributes to massive data pool and cloud. For instance, so famous technology brand like Intel has kept well afloat in the face of waning PC sales across the industry by refocusing on innovation.

The destination for intensive growth. Technology brands do not only benefit from wide markets but an ability to develop more rapidly than others. Innovations that the top technology brands have accumulated, along with the relative lack of manufacturer regulation give them an opportunity to reinvent their goods or services very easily. Rearrangements to software can happen quickly, requiring minimal input from their customer bases, testing and iterating ideas is core to the vision of these brands.

Built-in flexibility gives technology brands the opportunity to turn into different goods or service categories as they evolve along with customers' wishes and expectations. Here we can provide an example like Uber, which has evolved from a car app into a provider of some services. Besides, these up-to-date technology brands are not just catering to customers' needs but raising the bar for what's possible, not just meeting but managing the speed of life.

Following the famous leaders. Brands could follow the leaders by evolving marketing strategies. For example, Adobe sees how people act at work and home, and it suggests an expanded service portfolio that creates the value chain in the business sector and gets closer to the customer through mobile applications. Few have leveraged their platforms, like Amazon. What was designed as a shopping platform now powers content and the lessons learned in building that platform gave way to a successful cloud service business.

The success of these businesses and the strength of their brands have driven growth beyond the technology sphere. Brands in all sectors in the modern economy are including technology brands as business partners or platforms.

Operating for prospects. The most famous technology brands have become perceptive of marketers by using 
the equity built into their brands to allude at what lies beyond their goods and services. Many have seeded their next big bets, preparing customers for what may be next or positioning themselves as seers.

As technology becomes more a mirror of the self, events will continue to develop around automation. For example, Lenovo has moved beyond the ICT world with a slew of new smart gadget, from watches to laptops, powered by the innovation cloud platform that the brand itself is helping to develop.

Information technologies extend to our thinking with advancements in human-made intelligence. The most famous technology brands use human-made intelligence to develop deeper interface dependencies, for instance, Amazon with Alexa, Apple with Siri, etc. Nowadays, human-made intelligence is getting smarter, more cautionary, and anthropomorphic, with the ability to develop more close relationships with customers.

Human-made intelligence has the potential to not only enhance individuals' lives but to advance the capabilities of business, as we have seen with the continued applications of IBM's software.

The concept of "privacy exchange", trading personal information for perceived value - may also have a dividing effect on the amount of data people show, which will allow human-made intelligence to become more nuanced while putting pressure on more brands to develop human-made intelligence as a part of their ecosystems.

After finding a business idea, it is important to define the market niche. As we discussed, the market niche very often is free of competitors and guarantees financial success. The idea may be brilliant, although if it does not correspond to the chosen market niche, the business might fail.

We try to give an example. There is the idea to set up business related with growing and selling healthy food because the increasing income of population and a tendency to the healthy style of living causes the demand for these goods. However, if we choose the countryside as the market niche business would not be successful because population do not have high income and have own fruits and vegetables.

In the modern conditions of competition, it is important to find the market niche, which is free from competitors. Choosing the market niche, it is necessary to understand the prospects of market share development. It means that market niche must be in-demand not only today but also tomorrow and in the future. In other words, the particular business-idea must be unique for this market niche. In addition, it means that in this market niche there are no competitors who can satisfy the needs of customers and ways of satisfaction must correspond to their psychical, cultural, and economic features.

It is necessary to add the importance of barriers to entering the market. Here we define these market barriers, which prevent competitors from entering the market: exclusive contracts, licenses, patents, and knowhow. The brand can choose several market niches; however, for every niche, it has to prepare different strategies.

Experts of brand-management need to find the niche at which the brand would be oriented in the future. If the niche is interesting, business begins to give information about the brand to final customers. Although, it is necessary to investigate whether the customers need it. Such investigations provide an opportunity to find out strengths and weaknesses of the brand.

\section{Conclusions}

Our investigation allows making such a conclusion. Today's economy is characterized by the increasing role of non-material assets in a balance of companies. Additionally, the success of the company is caused by relations with customers and brand management.

There were analysed several business strategies of famous brands and concluded that if you want to have success, you need to find the own market niches. In the article, we analysed the experience of Apple, Google, and Coca-Cola brands which were the most successful in 2016. The experience of these brands is significant. Such success may be possible only if these brands use professional marketing tools and their niches.

We analysed several approaches to understanding the definition of market niche and defined some variants of using this concept: identification of concepts of market niche and target market segment; definition of a small market part, which corresponds to competitive advantages of the brand; identification of a special situation in the market when the name satisfies a new requirement that had not been satisfied yet.

According to made analysis, the market niche is characterised by these features: highly individual needs and demands for satisfying which it is necessary to have a range of complement goods and services; stable market potential; weak competitors.

The appearance of the market niche is caused by developing different situations in the market: target marketing; the unusual situation in the market; clustered marketing; horizontal marketing and vertical marketing.

There were defined the next steps of entering the new market by the brand: defining criteria for choosing a niche; analysing the influence of external environment on the brand operating in the particular niche; analysing opportunities of the brand in the niche; SWOT analysis of brand working in the niche; forecasting of the brand operation in the niche; preparing the rating of chosen marketing niches.

We made a list of market niches, which will be successful in the coming ten years. These are: Internet resources: big data; online courses; delivery service; 
wearable gadget; 3D-printing; robots; fuel cells and batteries; commercial property in regions; smart materials; auto components; health care; recycling; alternative energetics; space; escort of elderly people; franchising business; agriculture; geological prospecting and green projects. It was concluded that technology market niches are the most popular today. It is caused by the given factors: broad addressable markets; the destination for accelerated growth; following the famous leaders and operating for prospects.

\section{References:}

Aaker, D. (1996). Building Strong Brands. New York: The Free Press. (in English)

Aaker, D. (1991). Managing brand equity: Capitalizing on the value of a brand name. New York: The Free Press. (in English)

Aaker, D. (2014). Aaker on branding: 20 principles that drive success. New York, NY: Morgan James Publishing. (in English)

Aaker, D. (2011). Brand relevance: making competitors irrelevant. Retrieved from: http://johniduh.yolasite.com/ resources/brandrelevancemakingcompetitorsirrelevant.pdf1759758197.pdf (in English)

Liesio, J., Mild, P., Salo A. (2006). Preference programming for robust portfolio modelling and project selection. European Journal of operating research, 181(3), 1488-1505. (in English)

Hines, A. (2008). Thinking about the future: Guidelines for strategic foresight. Retrieved from: http://www.executiveforum.com/PDFs/AHinesSynopsis.pdf (in English)

Laut, A. (2011). Brendingovaya Politika kak faktor pov Shaniya konkurentosposobnosti organizatsii [Branding politics as a factor of improving the competitiveness of an organization]. Extended abstract of candidate's thesis. Ekaterinburg. (in Russian)

Tokarev, B. (2012). Metodika vybora rynochnykh nish vysokotekhnologichnykh produktov [Methodology of selection of market niches for high-tech products. Sovremennye tekhnologii upravleniya. Retrieved from: http://sovman.ru/article/1305/ (in Russian)

Best Global Brands 2016 Rankings. Retrieved from: http://interbrand.com/best-brands/best-globalbrands/2016/ranking/ (in English)

Vaigel, M. (2004). Poisk i osvoenie rynochnykh nish v marketingovoi deyatelnosti kommercheskikh organizatsiy [Searching and developing market niches in the marketing of commercial organizations]. Extended abstract of candidates thesis. Moscow. (in Russian)

Kotler, P. (2000). Marketing, management, Millennium edition. Prentice-Hall, Inc. (in English)

Rynochnaya nisha i ee vybor [Market niche and selection of it]. Retrieved from: http://biznesklubonline.com/ stati/242-rynochnaya-nisha-i-ee-vybor/ (in Russian) 